\title{
Effect of diet and rumen development on the composition of adipose tissue triglycerides of the calf
}

\author{
By G. A. GARTON aNd W. R. H. DUNCAN \\ Rowett Research Institute, Bucksburn, Aberdeen, $A B 2{ }_{9} S B$ \\ (Received I8 December 1968-Accepted I7 fanuary 1969)
}

\begin{abstract}
I. Samples of subcutaneous (inguinal) and perinephric adipose tissue were obtained, at slaughter, from each of twenty male calves. Three were neonatal animals, three were 3 days old and two were fed on reconstituted milk to appetite until they weighed $100 \mathrm{~kg}$. The other twelve calves were given milk until they reached $50 \mathrm{~kg}$ live weight; concentrates were then included in the diet until, at $60 \mathrm{~kg}$ live weight, six calves were slaughtered. The remaining six calves were raised to roo $\mathrm{kg}$ on concentrates alone. The weight of the empty reticulo-rumen of each slaughtered calf was recorded.

2. The component fatty acids of the adipose tissue triglycerides of the neonatal and 3 -day-old calves were very similar; about $80 \%$ consisted of oleic acid (18:I) and palmitic acid (16:0) and the remainder comprised stearic acid ( $18: 0$ ), palmitoleic acid ( $16: 1$ ) and myristic acid ( $14: 0$ ), together with very small amounts of other acids which, in the glycerides of the 3-dayold calves, included some evidently of colostral origin. The perinephric glycerides of both these groups of calves were somewhat more unsaturated than were those of subcutaneous adipose tissue.

3. The continued consumption of milk by the calves slaughtered at $60 \mathrm{~kg}$ live weight was reflected in the presence of enhanced proportions of $14: 0,18: 2,17: 0$ and $17: 1$ in the depot triglycerides and, in addition, very small amounts of branched-chain acids and trans $18: \mathrm{I}$ were detected. A similar fatty acid pattern was observed in the triglycerides of the calves which were given milk only until they were $100 \mathrm{~kg}$ live weight. In all these calves only limited growth of the rumen took place.

4. By contrast, the calves which were raised on solid feed from $60 \mathrm{~kg}$ to $100 \mathrm{~kg}$ and in which rumen development had taken place had depot triglycerides whose fatty acid composition resembled that found in adult animals. Increased proportions of stearic acid accompanied by relatively large amounts of trans I8: I were present, evidently as a result of the assimilation of the products of bacterial modification of dietary fatty acids in the rumen.

5. Regardless of the age of the calves and the over-all fatty acid composition of their tissue triglycerides, the intramolecular disposition of the fatty acids was similar in that saturated components were present esterified mainly in positions $I$ and 3 , and unsaturated acids for the most part in position 2 ; the only major exception to this distribution pattern was in respect of trans $18:$ I which, when present, was preferentially esterified to the primary alcoholic groups of the glycerol moiety as if it were a saturated acid.
\end{abstract}

It is well known that, in the adult ruminant animal, the triglycerides of perinephric adipose tissue are more saturated than those of subcutaneous depots owing largely to a higher content of stearic acid in the former (see Hilditch \& Williams, r964). This is ascribable (Duncan \& Garton, 1967) to the assimilation and selective deposition of stearic acid which results from the complete hydrogenation by rumen micro-organisms of $\mathrm{C}_{18}$ unsaturated fatty acids (oleic, linoleic and linolenic acids) derived from feed lipids. Isomeric forms of these unsaturated acids possessing trans double bonds are also formed by bacterial action, and the presence of such acids characterizes the tissue and milk lipids of the adult ruminant. These lipids also contain small proportions of iso and anteiso branched-chain fatty acids and $\mathrm{n}$-acids with an odd number of carbon atoms which, for the most part, originate from the intestinal digestion of the structural 
lipids of rumen bacteria. For recent reviews of lipid metabolism in the rumen see Garton (1965, 1967).

Compared with what is known about the composition of tissue triglycerides of adult domesticated ruminants, very little information is available in respect of the young animal before and during rumen development. In this paper we report the results of such an investigation on tissue triglycerides obtained from calves which were being used by colleagues at this Institute in a wider study (J. F. D. Greenhalgh \& M. Kay, to be published) on the effects of age, diet and live weight on over-all carcass composition.

\section{EXPERIMENTAL}

\section{Animals and their treatment}

Twenty Friesian male calves were used. Three, designated as calves I, 2 and 3 , were killed immediately after birth and a further three (calves 4,5 and 6 ) after they had been suckled by their dams for 3 days. All the other calves were suckled for 3 days and then given reconstituted dried whole milk; two calves (nos. 7 and 8) continued to receive the reconstituted milk to appetite until they attained $100 \mathrm{~kg}$ live weight, when they were killed. The milk intake of twelve calves was regulated such that, until they reached a live weight of $50 \mathrm{~kg}$, four animals (nos. 9, I0, II and I2) gained about $300 \mathrm{~g} /$ day, four (nos. I3, I4, I 5 and I6) gained about $500 \mathrm{~g} /$ day and four (nos. I7, I8, I9 and 20) gained about $700 \mathrm{~g} /$ day. The diet was then changed to include, in addition to milk, solid feed which comprised, in parts by weight, flaked maize 40 , oats $27 \cdot 6$, soya-bean meal II 4 , molassine meal II and fishmeal 8, together with 2 parts of an appropriate mixture of minerals and vitamins. Six of the calves (nos. 9, I0, I3, I4, I 7 and 18 ) were slaughtered when they reached $60 \mathrm{~kg}$ live weight. Milk was withdrawn from the diet of the remaining six calves (nos. I I, I2, I5, I6, I9 and 20) when each reached $60 \mathrm{~kg}$ live weight and thereafter, until they were slaughtered at $100 \mathrm{~kg}$ live weight, their diet consisted entirely of the solid feed; free access to drinking water was provided. Both during the period when milk was being replaced by solid feed and subsequently when solid feed alone was given the total intake of nutrients was regulated so that the appropriate pairs of calves continued to gain about 300,500 and $700 \mathrm{~g}$ live weight/calf per day.

\section{Tissues obtained at slaughter}

At slaughter the reticulo-rumen (subsequently referred to simply as the rumen) was removed from calves $4^{-20}$ inclusive; each rumen was washed thoroughly with water, allowed to drain, and the weight recorded.

Samples $(5-10 \mathrm{~g})$ of subcutaneous and perinephric adipose tissue were taken from each carcass. In the neonatal and 3 -day-old calves the only visible subcutaneous adipose tissue was in the inguinal region and so, for comparative purposes, it was from this anatomical site in each of the older animals that the subcutaneous tissue sample was obtained.

\section{Analytical procedures}

The adipose tissue samples were chopped into small pieces and extracted with acetone as described by Duncan \& Garton (1967) to yield the lipid which, in each 
instance, was found by thin-layer chromatography (Garton \& Duncan, 1964) to consist entirely of triglyceride. The triglyceride preparations were stored for up to a week at $+\mathrm{I}^{\circ}$ under nitrogen until they were analysed. Using methods previously outlined by Duncan \& Garton (1967), the component fatty acids of the triglycerides were determined by gas-liquid chromatography, their content of trans unsaturated acid by infrared spectroscopy and their intramolecular disposition by the pancreatic lipase procedure. Fatty acid compositions, determined as percentage by weight, were converted into molecular percentages (i.e. moles/100 moles). In the Tables and, as appropriate, in the text the acids are designated by the shorthand system of Dole, James, Webb, Rizack \& Sturman (1959) which shows the number of carbon atoms per molecule, followed by the number of double bonds.

\section{RESULTS AND DISCUSSION}

The component fatty acids of the adipose tissue triglycerides of the neonatal and 3-day-old calves are shown in Table 1 .

In the glycerides from both adipose tissue sites in the neonatal calves palmitic acid $(\mathrm{I} 6: 0)$ and oleic acid (I8:I) together comprise about $80 \%$ of the total acids and the remaining components consist entirely of myristic acid (I4:0), myristoleic acid (I4: I),

Table I. Proportions of fatty acids in adipose tissue triglycerides of neonatal and 3 -day-old calves

(Values as moles/100 moles total fatty acids)

\begin{tabular}{|c|c|c|c|c|c|c|c|}
\hline \multirow{2}{*}{$\begin{array}{l}\text { Calf } \\
\text { no. }\end{array}$} & \multirow{2}{*}{$\begin{array}{l}\text { Adipose } \\
\text { tissue } \\
\text { site }\end{array}$} & \multicolumn{6}{|c|}{ Fatty acids } \\
\hline & & $14: 0$ & $16: 0$ & $16: 1$ & I8:0 & I $8: \mathrm{I}$ & Others* \\
\hline \multicolumn{8}{|c|}{ Neonatal calves } \\
\hline I & $\begin{array}{l}\text { Subcutaneous } \dagger \\
\text { Perinephric }\end{array}$ & $\begin{array}{l}I \cdot 9 \\
I \cdot 5\end{array}$ & $\begin{array}{l}38 \cdot 0 \\
33 \cdot 7\end{array}$ & $\begin{array}{l}4.3 \\
6.6\end{array}$ & $\begin{array}{r}\text { I3.5 } \\
8 \cdot 0\end{array}$ & $\begin{array}{l}4 r \cdot 9 \\
49 \cdot 6\end{array}$ & $\begin{array}{l}0.4 \\
0.6\end{array}$ \\
\hline 2 & $\begin{array}{l}\text { Subcutaneous } \\
\text { Perinephric }\end{array}$ & $\begin{array}{l}2 \cdot 5 \\
\mathrm{I} \cdot 5\end{array}$ & $\begin{array}{l}37 \cdot 6 \\
32 \cdot 1\end{array}$ & $\begin{array}{l}6 \cdot 9 \\
9 \cdot 0\end{array}$ & $\begin{array}{r}10 \cdot x \\
5.4\end{array}$ & $\begin{array}{l}4 I \cdot 9 \\
5 I \cdot 3\end{array}$ & $\begin{array}{l}\mathbf{1} 0 \\
0.7\end{array}$ \\
\hline 3 & $\begin{array}{l}\text { Subcutaneous } \\
\text { Perinephric }\end{array}$ & $\begin{array}{l}2 \cdot 2 \\
2 \cdot 7\end{array}$ & $\begin{array}{l}35 \cdot 7 \\
36 \cdot 3\end{array}$ & $\begin{array}{l}4 \cdot 8 \\
8 \cdot 2\end{array}$ & $\begin{array}{r}16.8 \\
9.8\end{array}$ & $\begin{array}{l}39 \cdot 2 \\
4 x \cdot 4\end{array}$ & $\begin{array}{l}1 \cdot 3 \\
1 \cdot 6\end{array}$ \\
\hline \multicolumn{8}{|c|}{ 3-day-old calves } \\
\hline 4 & $\begin{array}{l}\text { Subcutaneous } \\
\text { Perinephric }\end{array}$ & $\begin{array}{l}2 \cdot 8 \\
I \cdot 5\end{array}$ & $\begin{array}{l}44^{\prime 2} \\
35^{\prime} 1\end{array}$ & $\begin{array}{l}3 \cdot 8 \\
4 \cdot 5\end{array}$ & $\begin{array}{l}13.5 \\
10.0\end{array}$ & $\begin{array}{l}33 \cdot 4 \\
47^{\cdot} \mathrm{I}\end{array}$ & $\begin{array}{l}2 \cdot 3 \\
I \cdot 8\end{array}$ \\
\hline 5 & $\begin{array}{l}\text { Subcutaneous } \\
\text { Perinephric }\end{array}$ & $\begin{array}{l}2 \cdot 5 \\
1 \cdot 7\end{array}$ & $\begin{array}{l}39 \cdot 6 \\
35 \cdot 0\end{array}$ & $\begin{array}{l}4 \cdot 2 \\
5 \cdot 1\end{array}$ & $\begin{array}{l}\text { I } 5.4 \\
\text { I I.0 }\end{array}$ & $\begin{array}{l}36 \cdot 8 \\
43 \cdot 7\end{array}$ & $\begin{array}{l}I \cdot 5 \\
3.5\end{array}$ \\
\hline 6 & $\begin{array}{l}\text { Subcutaneous } \\
\text { Perinephric }\end{array}$ & $\begin{array}{l}3 \cdot 4 \\
2 \cdot 2\end{array}$ & $\begin{array}{l}4 I \cdot 7 \\
28 \cdot 6\end{array}$ & $\begin{array}{l}3 \cdot 5 \\
5 \cdot 6\end{array}$ & $\begin{array}{l}14 \cdot 2 \\
10 \cdot 4\end{array}$ & $\begin{array}{l}36 \cdot 4 \\
50 \cdot 2\end{array}$ & $\begin{array}{l}0.8 \\
3.0\end{array}$ \\
\hline
\end{tabular}

palmitoleic acid (I6:1) and stearic acid (I8:0); acids of exogenous origin such as $\mathrm{n}$-acids with an odd number of carbon atoms, branched-chain acids and acids with trans double bonds were not detected. This over-all simple composition resembles that reported for the triglycerides of neonatal lambs (Downing, 1964; Shorland, Body \& 
Gass, 1966; Garton \& Duncan, I969). Garton \& Duncan (1969) concluded that, in the sheep, plasma triglycerides do not pass the placental barrier; this situation appears to exist also in the cow, indicating that, although maternal phospholipids (Shorland et al. 1966) and free fatty acids (Van Duyne, Parker, Havel \& Holm, I960) may be transferred to the foetus, the formation of triglycerides is probably dependent almost entirely on the supply of fatty acids synthesized de novo in the foetal tissues.

As would be expected, the component fatty acids of the triglycerides from the 3 -dayold calves were very similar to those of the neonatal animals, though the subcutaneous triglycerides did contain somewhat more (about $5 \%$ ) $16: 0$ and a correspondingly lower proportion of $18: 1$; in addition, small amounts of $17: 0,17: 1$ and $18: 2$, evidently of colostral origin, were detected.

In view of the well-known observation that, in adult animals, subcutaneous triglycerides are more unsaturated than those within the body cavity, it is of interest to note that in the neonatal and very young calves the proportion of total saturated acids (14:0, I6:0 and 18:0) in the inguinal (subcutaneous) glycerides was consistently greater than in the triglycerides of perinephric tissue which contained correspondingly increased proportions of both $16: \mathrm{I}$ and $\mathrm{I} 8: \mathrm{I}$.

In Table 2 are given the analytical results for the fatty acid components of the subcutaneous and perinephric triglycerides of the calves which were slaughtered at $60 \mathrm{~kg}$ or $100 \mathrm{~kg}$ live weight.

The fatty acid composition of the glycerides of calves $9,10,13,14,17$ and 18 , which received only small amounts of solid feed during the last stages of their growth to $60 \mathrm{~kg}$ live weight, reflects the assimilation of fatty acids derived mainly from milk glycerides; compared with the glycerides of the 3 -day-old calves, more $\mathrm{I}_{4}: 0, \mathrm{I} 8: 2$, I $7: 0$ and $17: \mathrm{I}$ were present, and $18: 3$ together with branched-chain acids and trans unsaturated acids were detected in very small amounts. All these additional acids are known constituents of bovine milk lipids (see Garton, I 1963 ). The calves ( 7 and 8 ) which were reared to $100 \mathrm{~kg}$ live weight on milk alone produced depot glycerides which were very similar in composition to those of the $60 \mathrm{~kg}$ calves. The stearic acid content of the perinephric glycerides of all these animals was slightly greater than that of the corresponding subcutaneous glycerides, suggesting that some measure of preferential incorporation of exogenous stearic acid had taken place. As previously discussed by Duncan \& Garton (1967) with respect to tissues of the sheep, the capacity to effect preferential assimilation of exogenously supplied stearic acid into triglycerides appears to be a characteristic of adipose tissue within the body cavity, particularly perinephric tissue.

As Table 3 shows, only limited growth of the rumen had taken place in the calves which were slaughtered at $60 \mathrm{~kg}$ live weight and in the calves which received only milk until they reached roo $\mathrm{kg}$ live weight. The influence of solid feed in promoting rumen development (cf. McGilliard, Jacobson \& Sutton, 1965 ) is reflected in the rumen weights for calves II, I2, I5, I6, I9 and 20 and in the fatty acid composition of their depot glycerides. Compared with the glycerides of the milk-fed calves (nos. 7 and 8), the presence of greater proportions of stearic acid and of much more trans 18 : I (see Table 2 ) is evidently associated with the establishment in the rumen of bacterial 
Vol. 23

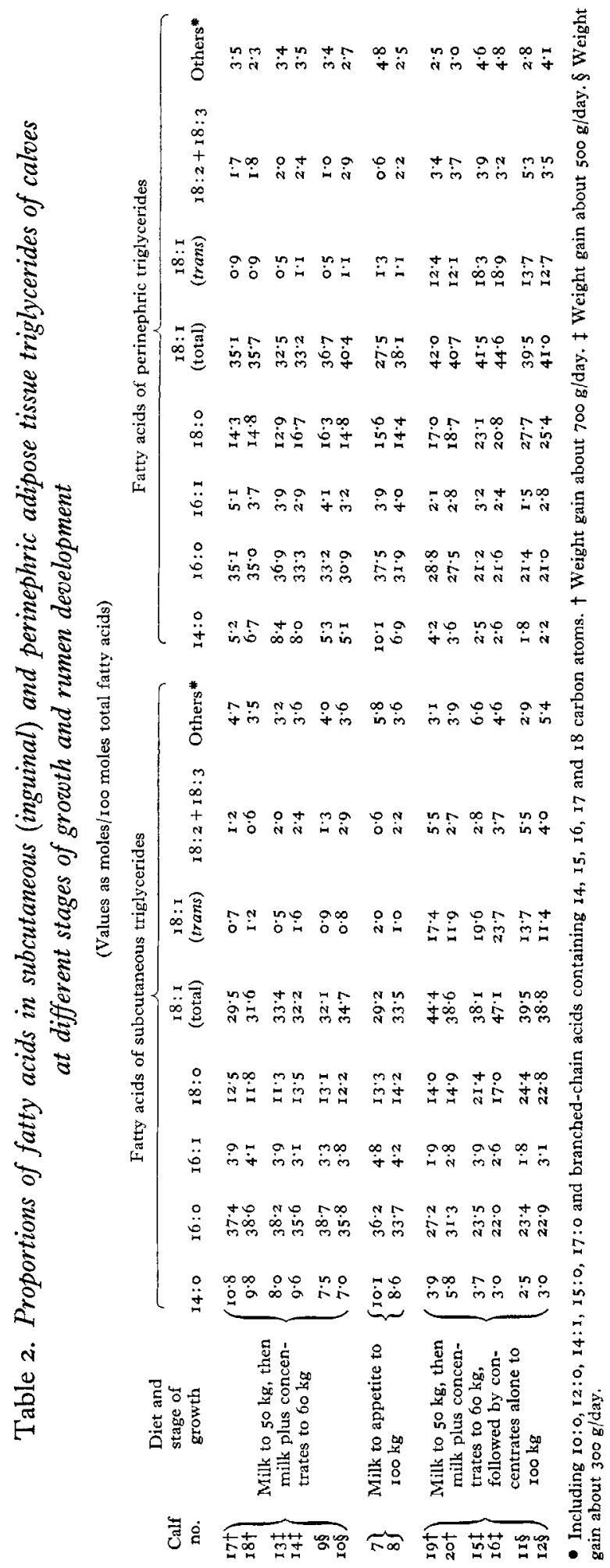


species which can effect isomerization and hydrogenation of the $\mathrm{C}_{18}$ unsaturated acids of the dietary maize and oats. In the triglycerides of calves I I and I 2 which received solid feed for the longest time, the proportions of stearic acid and total i 8 : I (Table 2) resemble those found in the corresponding triglycerides of the mature ox (cf. Hilditch $\&$ Williams, 1964). Though, for clarity of presentation, values for minor component

\section{Table 3. Average weights of the reticulo-rumen of calves at different stages of growth}

\begin{tabular}{|c|c|c|}
\hline Calf nos. & Diet and stage of growth when slaughtered & $\begin{array}{l}\text { Average weight } \\
\text { of reticulo- } \\
\text { rumen (g) }\end{array}$ \\
\hline 4,5 and 6 & Suckled for 3 days & 202 \\
\hline 17 and $18 *$ & & $(434$ \\
\hline $\left.\begin{array}{r}3 \text { and r } 4 \nmid \\
9 \text { and rof }\end{array}\right\}$ & Milk to $50 \mathrm{~kg}$, then milk plus concentrates to $60 \mathrm{~kg}$ & $\left\{\begin{array}{l}639 \\
671\end{array}\right.$ \\
\hline 7 and 8 & Milk to appetite to $100 \mathrm{~kg}$ & 752 \\
\hline $\left.\begin{array}{l}\text { I9 and } 20^{*} \\
\text { I } 5 \text { and } 16+ \\
\text { I } 1 \text { and } 12 f\end{array}\right\}$ & $\begin{array}{l}\text { Milk to } 50 \mathrm{~kg} \text {, then milk plus concentrates to } 60 \mathrm{~kg} \\
\text { followed by concentrates alone to } 100 \mathrm{~kg}\end{array}$ & $\left\{\begin{array}{l}3248 \\
3183 \\
2496\end{array}\right.$ \\
\hline
\end{tabular}

* Weight gain about $700 \mathrm{~g} /$ day. $\dagger$ Weight gain about $500 \mathrm{~g} /$ day. $\ddagger$ Weight gain about $300 \mathrm{~g} /$ day.

\section{Table 4. Positional distribution of $C_{16}$ and $C_{18}$ fatty acids in perinephric triglycerides of calves}

(Values as moles/100 moles to nearest whole number)

\begin{tabular}{|c|c|c|c|c|c|c|}
\hline \multirow[b]{2}{*}{$\begin{array}{l}\text { Calf } \\
\text { no.* }\end{array}$} & & \multicolumn{5}{|c|}{ Fatty acid } \\
\hline & & 16:0 & 16:I & I $8: 0$ & $\begin{array}{l}\mathbf{1} 8: \mathrm{I} \\
(\mathrm{cis})\end{array}$ & $\begin{array}{c}\text { I8: I } \\
\text { (trans) }\end{array}$ \\
\hline \multirow[t]{3}{*}{6} & Triglycerides & 29 & 6 & 10 & 50 & ndt \\
\hline & 2-Monoglycerides & I3 & 7 & 3 & 73 & - \\
\hline & $\%$ in 2-position $f$ & 15 & 42 & 9 & 48 & 一 \\
\hline \multirow[t]{3}{*}{13} & Triglycerides & 37 & 4 & I3 & 32 & $\mathbf{I}$ \\
\hline & 2-Monoglycerides & 23 & 5 & 4 & 48 & nd \\
\hline & $\%$ in 2 -position & 21 & 44 & II & 50 & 一 \\
\hline \multirow[t]{3}{*}{7} & Triglycerides & $3^{8}$ & 4 & 16 & 27 & I \\
\hline & 2-Monoglycerides & 25 & 6 & 4 & 39 & nd \\
\hline & $\%$ in 2-position & 22 & 52 & 8 & 48 & - \\
\hline \multirow[t]{3}{*}{ II } & Triglycerides & $2 \mathrm{I}$ & 2 & 28 & 26 & 14 \\
\hline & 2-Monoglycerides & I3 & 3 & 7 & 49 & 8 \\
\hline & $\%$ in 2-position & $2 I$ & 55 & 8 & 64 & 18 \\
\hline \multirow[t]{3}{*}{12} & Triglycerides & 21 & 3 & 25 & 28 & 13 \\
\hline & 2-Monoglycerides & 17 & 3 & 9 & 47 & I0 \\
\hline & $\%$ in 2-position & 26 & 33 & I 2 & 56 & 25 \\
\hline
\end{tabular}

* For diet and stage of growth see footnotes to Table $3 . \dagger$ n.d. $=$ not detected. $\downarrow$ Derived from the expression

$$
\frac{\text { (moles/100 moles fatty acid in } 2 \text {-monoglycerides) } \times 100}{\text { (moles/100 moles same fatty acid in triglycerides) } \times 3}
$$

acids are not given in Table 2, the triglycerides of calves I I and 12 contained the greatest amounts of branched-chain acids and $1_{5}: 0$ and $17: 0$, all of which derive from the digestion of the structural lipids of rumen bacteria. The inguinal triglycerides from the calves with developed rumens were less saturated than those from the perinephric 
region though they contained more stearic acid and less $\mathrm{I} 8: \mathrm{I}$ than is usully present in triglycerides from more conventional subcutaneous bodily sites (e.g. brisket, rump) of adult animals (see, for example, Hartman \& Shorland (196r) and Dahl (1962)); the over-all composition of the inguinal triglycerides of calves I I and I2 was similar to that reported by Adhikari (1964) for triglycerides from the anal region of the adult ox.

Samples of the perinephric triglycerides of calves 6,7, I I, I2 and I 3 were analysed (Table 4) for the positional distribution of their major component acids. Saturated acids ( $16: 0$ and $18: 0$ ) are preferentially esterified to the primary alcoholic groups (positions $I$ and 3 ) of the glycerol moiety of the triglycerides and the $I 8: I$ is for the most part esterified to the secondary alcoholic group (position 2). This distribution pattern obtains regardless of the age of the calf from which the sample was taken and it closely resembles the pattern previously observed in triglycerides from several different anatomical sites in adult sheep (Duncan \& Garton, 1967) and lambs (Garton \& Duncan, 1969). As exemplified in Table 4 by the values for calves I I and I2, the trans I 8: I was present mainly in positions I and 3 of the triglyceride molecules. This is in marked contrast to the notable predominance of cis 18: I (i.e. oleic acid) among the acids esterified in position 2. A similar positional distribution of trans unsaturated acid was noted in sheep triglycerides by Duncan \& Garton (1967) and in the triglycerides of rats which had been given a diet containing 'isomerized' groundnut oil (Raulin, Loriette \& Clément, I963). These observations indicate that unsaturated fatty acids possessing trans double bonds are treated metabolically as if they were saturated acids and this behaviour may be associated with the fact that, compared with unsaturated acids of the cis configuration, the presence of a trans bond involves but little deformation of a straight chain of carbon atoms (cf. Carroll, 1965).

\section{REFERENCES}

Adhikari, S. (I964). Pakist. F. scient. ind. Res. 7, 24.

Carroll, K. K. (1965). F. Am. Oil Chem. Soc. 42, 5 I6.

Dahl, O. (1962). F. Sci. Fd Agric. 13, 520.

Dole, V. P., James, A. T., Webb, J. P. W., Rizack, M. A. \& Sturman, M. F. (1959). F. clin. Invest. 38, I544.

Downing, D. T. (1964). F. Lipid Res. 5, 210.

Duncan, W. R. H. \& Garton, G. A. (1967). F. Sci. Fd Agric. 18, 99.

Garton, G. A. (1963). F. Lipid Res. 4, 237.

Garton, G. A. (I965). In Physiology of Digestion in the Ruminant, p. 39o. [R. W. Dougherty, editor.] Washington, D.C.: Butterworths.

Garton, G. A. (1967). Wld Rev. Nutr. Diet. 7, 225.

Garton, G. A. \& Duncan, W. R. H. (1964). Biochem. F. 92, 472.

Garton, G. A. \& Duncan, W. R. H. (1969). F. Sci. Fd Agric. 20, 39.

Hartman, L. \& Shorland, F. B. (I961). N.Z. Fl Sci. 4, I6.

Hilditch, T. P. \& Williams, P. N. (1964). The Chemical Constitution of Natural Fats, 4th ed. Ch. 3 . London: Chapman \& Hall.

McGilliard, A. D., Jacobson, N. L. \& Sutton, J. D. (1965). In Physiology of Digestion in the Ruminant, p. 39. [R. W. Dougherty, editor.] Washington, D.C.: Butterworths.

Raulin, J., Loriette, C. \& Clément, G. (r963). Biochim. biophys. Acta 7o, 642.

Shorland, F. B., Body, D. R. \& Gass, J. P. (1966). Biochim. biophys. Acta r25, 207.

Van Duyne, C. M., Parker, H. R., Havel, R. J. \& Holm, L. W. (1960). Am. F. Physiol. r99, 987. 